\title{
Influence of carrier media physical properties on start-up of moving attached growth systems
}

\author{
Joana Dias ${ }^{\mathrm{a}}$, Mell Bellingham ${ }^{\mathrm{b}}$, Junaid Hassan ${ }^{\mathrm{b}}$, Mark Barrett $^{\mathrm{b}}$, Tom Stephenson ${ }^{\mathrm{a}}$, Ana \\ Soares $^{\mathrm{a}}$ \\ ${ }^{a}$ Cranfield University Water Sciences Institute, Cranfield, MK43 OAL, UK. \\ ${ }^{b}$ Warden Biomedia, 31 Sundon Industrial Estate, Dencora Way, Luton, Bedford, LU3 3HP, UK.
}

\section{Graphical abstract:}

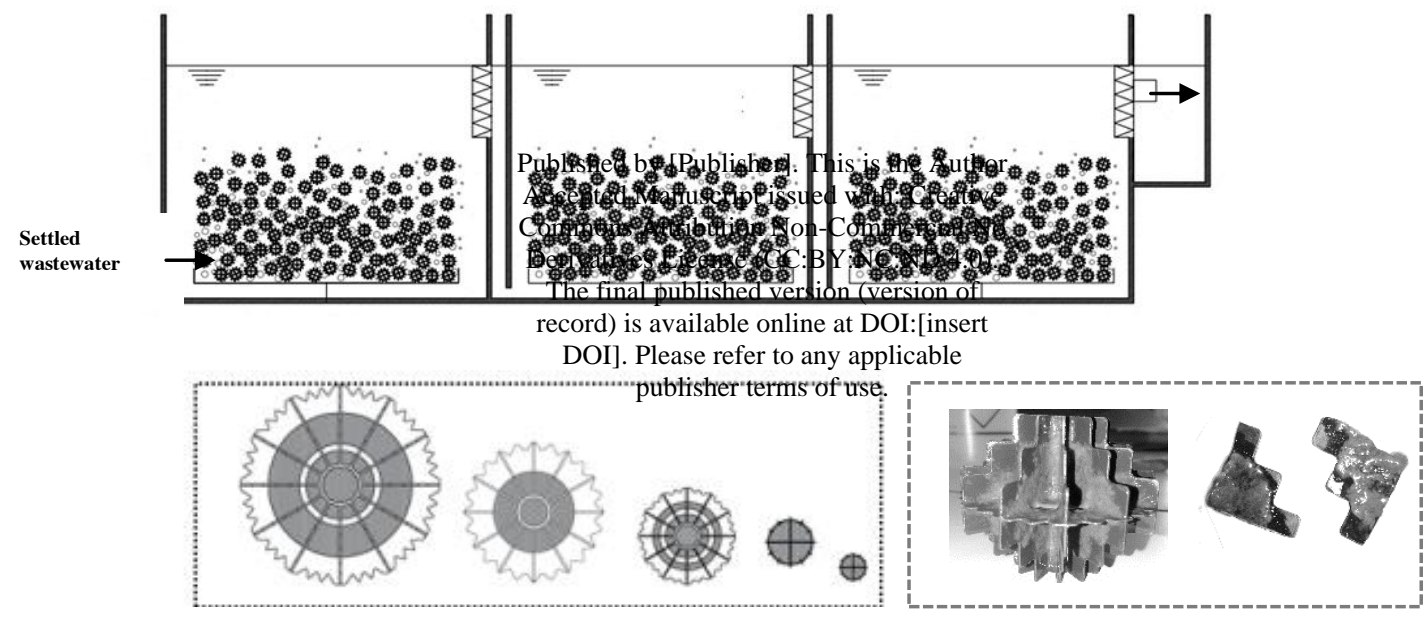




\title{
Influence of carrier media physical properties on start-up of moving bed biofilm systems
}

\author{
Joana Dias $^{\text {a }, \text { Mell Bellingham }}{ }^{\mathrm{b}}$, Junaid Hassan ${ }^{\mathrm{b}}$, Mark Barrett ${ }^{\mathrm{b}}$, Tom Stephenson ${ }^{\mathrm{a}}$, Ana \\ Soares $^{\mathrm{a}^{*}}$ \\ ${ }^{a}$ Cranfield University Water Sciences Institute, Cranfield, MK43 OAL, UK. \\ ${ }^{b}$ Warden Biomedia, 31 Sundon Industrial Estate, Dencora Way, Luton, Bedford LU3 3HP, UK
}

Highlights:

- Three spherical and two cylindrical shaped carrier media were tested.

- Faster biofilm formation rates were observed with the spherical carrier media.

- $\quad$ Larger voidage of the spherical carrier media improved COD and ammonia removal.

- Carrier media physical properties and hydraulic efficiency played a role on start-up.

- $\quad$ Start-up was not a function of carrier media protected surface area. 


\section{Influence of carrier media physical properties on start-up of}

\section{Abstract}

8 Five carrier media with different shapes (spherical and cylindrical), sizes, voidage and

9 protected surface areas $\left(112-610 \mathrm{~m}^{2} / \mathrm{m}^{3}\right)$ were studied in a pilot scale moving bed

22 Keywords: Biofilm formation rate, biofilm detachment, dimensionality, moving

23 * attached growth, start-up, voidage.

*Corresponding author at Cranfield Water Science Institute, Cranfield University, Vincent Building, Cranfield, Bedfordshire, MK43 0AL, UK. Tel.: +44 (0) 1234 758121. E-mail address: a.soares@cranfield.ac.uk (A. Soares). 


\section{Introduction}

2 The need to meet increasingly stringent discharge limits has made biofilm processes

3 popular for the removal of organic pollutants and nitrogen in wastewater treatment plants

4 (WWTPs) (Barwal and Chaudhary, 2016). Moving bed biofilm systems, such as submerged

5 aerated filters (SAFs) (structured or random packed) (Holloway and Soares, 2018), moving

6 bed biofilm reactor (MBBRs) and integrated fixed film activated sludge (IFAS) use buoyant

7 carrier media as a biofilm growth support material. MBBRs have been established in the past

825 years as robust, versatile and compact solutions and have been successfully implemented

9 in municipal and industrial wastewater treatment (Leyva-Díaz et al., 2013; Ødegaard, 2016).

10 The initial biofilm adhesion plays a crucial role on attached growth systems (Mao et al.,

11 2017; Tang et al., 2017). Due to the nature of the process the time required to achieve a well-

12 established biofilm can vary considerably from 1 to 6 weeks (Bassin et al., 2016; Dong et al.,

13 2015; Leyva-Díaz et al., 2013; Tang et al., 2016). Start-up duration has been a major

14 drawback on full-scale applications especially in nitrification processes (Lackner et al., 2009)

15 due to the slow growth rate of nitrifiers (Habouzit et al., 2014; Rikmann et al., 2018; Zekker

16 et al., 2016).

17 Bacterial adhesion to support surfaces has been extensively studied, and physical (size,

18 shape, density, roughness) and chemical properties (surface materials: plastic, foam, woven,

19 ceramic, glass, etc. and chemical modified polymer) have been shown to strongly affect early

20 stages of biofilm formation (Deng et al., 2016; Eldyasti et al., 2012). Biofilm formation

21 occurs after initial cell adhesion to the surface of the carrier media that then leads to bacteria

22 accumulation and extracellular polymeric substances (EPS) production. This helps bacteria 
1 bind and form the biofilm (Zhu et al., 2015). However, bacterial adhesion and subsequent

2 biofilm development is a dynamic process that can be affected by external factors such as

3 operating conditions, organic and nutrient loading and hydrodynamics within the reactor (Liu

4 and Tay, 2002; Pellicer-Nàcher and Smets, 2014). The latter plays a critical role during start-

5 up as it controls biofilm detachment caused by shear forces (superficial air velocity) and

6 abrasion (carrier media concentration) (Goel et al., 2011; Mao et al., 2017). To ensure a fast-

7 start up and stable biofilm formation a balance has to be achieved between biofilm growth

8 and detachment processes (Lackner et al., 2009).

9 To date, there have been limited studies on start-up of moving attached growth systems

10 (Zekker et al., 2012). Most studies identified in the literature are performed at the laboratory

11 scale, and focus on strategies to accelerate the adhesion of the microorganisms, to the carrier

12 reducing the start-up duration. Zhu et al. (2015) fed a 9 L laboratory scale reactor with easy

13 biodegradable substrates (synthetic wastewater) inoculated with activated sludge from a

14 secondary clarifier. The reactor was used to describe different start-up stages in biofilm

15 systems with a cylindrical shape carrier media with a protected surface area of $460 \mathrm{~m}^{2} / \mathrm{m}^{3}$ (no

16 information provided about the carrier media material). Stable COD and ammonia removals

17 of $92 \%$ and $50 \%$ were achieved after 6 and 14 days of start-up respectively (Zhu et al., 2015).

18 The same strategy was used by Bassin et al. (2016) on the start-up using two different carrier

19 media; a cylindrical (high density polyethylene) and chip shaped (virgin polyethylene with

20 additives) media with 500 and $3000 \mathrm{~m}^{2} / \mathrm{m}^{3}$ at 50 and $8.3 \%$ filling ratio. Twenty to thirty days

21 were necessary for a constant attached biofilm to be achieved. Seeding sludge and synthetic

22 wastewater was also used in Mao et al. (2017) where start-up was compared using three high 
1 density polyethylene (HDPE) carriers (two modified and one unmodified). Modified material

2 using PQAS-10 polyquaternium-10 and cationic polyacrylamides (CPAM) resulting in 13, 19

3 and 27 days, respectively. Batch feeding and prolonged hydraulic retention times were

4 adopted as a start-up strategy in Tang et al. (2016) using a round polyethylene ball and start-

5 up was achieved in only 6 days. These studies mainly demonstrate the dynamic nature of the

6 process but also highlight the variation of how start-up is interpreted and defined. Start-up in

7 moving attached growth systems has been described in a multitude of parameters, including:

8 biofilm growth, time to form a fully developed biofilm, biofilm activity and reactor

9 performance (i.e. substrate removal efficiencies) (Bassin et al., 2016; Mao et al., 2017; Tenno 10 et al., 2016; Zekker et al., 2017; Zhu et al., 2015)

11 Research on moving attached growth system start-up has been limited so far and to date,

12 no studies have investigated the relationships between carrier media physical properties and

13 start-up. The significance of this is emphasised in the importance of start-up towards

14 achieving low commission periods and treatment robustness during steady state (Rikmann et 15 al., 2014; Zekker et al., 2012).

16 This in turn can lead to improvement of the economic competitiveness of the moving 17 attached growth system technology. Therefore, this study aims to investigate how carrier 18 media physical properties influence process start-up using real wastewater. The expected 19 outcome of this work is intended to provide guidance for design and start-up of a full-scale 20 moving attached growth system plant. Furthermore, the fast biofilm formation rate, can be of 21 benefit for operation conditions modification (increased flow and organic loading) as well as 
1 for upgrade of existing wastewater treatment plants contributing to the extended application

2 of moving attached growth systems.

\section{2. Material and methods}

\section{$4 \quad$ 2.1. Pilot plant setup and operation conditions}

A $2 \mathrm{~m}^{3}$ rectangular shaped pilot plant divided into three separate aerobic cells of equal

6 volume (1.0 m width $\times 1.5 \mathrm{~m}$ length and $1.30 \mathrm{~m}$ height), was designed to study process start-

7 up. Medium bubble aeration was utilised to supply the required aeration and mixing. The

8 pilot was designed to cope with variable air velocities $3.6-18.7 \mathrm{~m}^{3} / \mathrm{m}^{2} . \mathrm{h}$ and wastewater

9 flows, ranging from $2.5-18 \mathrm{~m}^{3} /$ day. Air and wastewater flows were normalised per protected

10 surface area of media. Wastewater distribution was enhanced by the instalment of two baffles

11 on the cells. The five carrier media with different physical properties investigated were

12 supplied by Warden Biomedia (Table 1). Media 1, 2 and 3 were spherical media with a

13 protected surface area of 112,149 and $220 \mathrm{~m}^{2} / \mathrm{m}^{3}$ respectively whilst Media 4 and 5 were

14 cylindrical in shape with a protected surface area of 350 and $610 \mathrm{~m}^{2} / \mathrm{m}^{3}$ (Table 1). The pilot

15 plant was fed with settled wastewater from Cranfield University wastewater treatment plant

16 (Cranfield, UK) during 2016-2018. Each media was study for 60 days, covering a total of 300

17 days for the 5 media. The organic and nutrient loading per surface area was kept constant by

18 fixing the media filling ratio at $60 \%$, within the values recommended in literature (McQuarrie

19 and Boltz, 2011), by varying the wastewater flow rate. The pilot-plant was designed to keep

20 stable dissolved oxygen levels by delivering variable air flow velocities (between 3.6-18.7

$21 \mathrm{~m} 3 / \mathrm{m} 2 . \mathrm{h}$ ) and variable wastewater flow (between 2.5-18.0 m3/day). The start-up was done

22 with clean media directly transferred to the tank. No foam formation was observed. 


\subsection{Chemical analysis}

The wastewater of the influent and effluent was sampled three times a week during process start-up.

Samples were analysed for total 5-day carbonaceous biochemical oxygen demand $\left(\mathrm{BOD}_{5}\right)$ and soluble $\mathrm{BOD}_{5}$, total and volatile suspended solids (TSS and VSS) according to standard methods (APHA, 2005). Total and soluble chemical oxygen demand (tCOD and sCOD), ammonium-nitrogen $\left(\mathrm{NH}_{4}{ }^{+}-\mathrm{N}\right)$, and nitrate-nitrogen $\left(\mathrm{NO}_{3}^{-}-\mathrm{N}\right)$ were analysed using Merck cell tests kits (Merck KGaA, Darmstadt, Germany) and measured with a NOVA60 photometer (VWR, UK). Temperature, dissolved oxygen (DO) and $\mathrm{pH}$ were measured onsite daily using portable meters (HACH HQ40d; Camlab, Cambridge, UK).

Statistical analysis was completed using the software IBM SPSS Statistics 23 and results checked for normality using Shapiro-Wilk tests. ANOVA tests were applied for the normal distributed data. Statistical differences were based on $95 \%$ of the confidence level $(p<0.05)$.

Attached growth biofilm on the carriers was analysed two to three times a week following the procedure described in Regmi et al. (2011). Carriers were sampled and dried at $105^{\circ} \mathrm{C}$ overnight and weighed. The biofilm was removed by placing the carriers in a $\mathrm{H}_{2} \mathrm{SO}_{4}$ solution $(2 \mathrm{~N})$ and stirred vigorously for 24 hours. The carriers were washed with tap water then biofilm brushed off and dried at $105^{\circ} \mathrm{C}$. The total attached biofilm was calculated based on the difference in media dry weight before and after removing all biofilm attached. The results were expressed as grams of total solids per metre square of protected surface area of carrier media (g TS $/ \mathrm{m}^{2}$ ). Carriers were sampled from the three cells of the pilot plant (10 carriers of Media 1, 2 and 3 and 40 carriers of Media 4 and 5). 
1 Protected surface area was defined in this study as the area of carrier covered with

2 biofilm. The protected surface area was calculated for each media. Individual carriers were

3 cut and separated into small pieces and photographed. Comparisons were made between the

4 area covered with biofilm and the area without biofilm attached. All the images were

5 analysed using ImageJ Software and biofilm coverage area determined.

6 Organic removal performance was evaluated according to Ødegaard (Ødegaard, 2006).

7 An "obtainable removal rate" was calculated based on $100 \%$ solids separation. Influent tCOD

8 and effluent sCOD were compared with flow and protected surface area.

Equation (1) was used to fit a curve to the attached biofilm measured (Szilágyi et al., 2013). Where $m(t)$ is the attached biofilm as a function of time, $m_{\max }$ the maximum amount of

11 biofilm and $K_{m}$ coefficient of growth. The curve was fitted by manipulating the $K_{m}$ in order to 12 obtain the best fitted curve (Szilágyi et al., 2013).

$$
m(t)=m_{\max } \frac{t}{K_{m}+t}
$$

$$
\text { Biofilm thickness was measured through Optical Coherence Tomography (OCT) }
$$

14 using a Thorlabs Standard (SR-OCT 930nm; Thorlabs. Germany), with a refractive index of

151.33 (water). The media was cut into small pieces with a surgical scalpel and 20 images captured from different pieces of the carriers. Biofilm thickness was estimated based on the 17 average of 60 measurements. Extracellular polymeric substances (EPSs) were determined following biofilm

19 detachment from the media using the methodology described by Le-Clech et al. (2006).

20 Carbohydrate and protein concentrations were determined according to the Dubois phenol- 
1 sulphuric acid method (UV490 nm) with D-glucose (Acros Organics, UK) as the standard

2 (Dubois et al., 1956) and Protein by the Folin method (UV750 nm) with bovine serum

3 albumin (BSA) (Sigma-Aldrich, UK) as the standard (Lowery et al., 1951) respectively. Observed yields were calculated based on Eldyasti et al. (2012) using the linear

5 regression between the cumulative production of volatile suspended solids (VSS) in the 6 effluent and the cumulative COD removed ( $\left.\mathrm{tCOD}_{\mathrm{in}}-\mathrm{SCOD}_{\text {out }}\right)$.

8 et al. (2005) and Eldyasti et al.(2012) (Equation 2).

$$
k_{d e}=\frac{Q \times\left[V S S_{\text {out }}\right]}{A \times M_{t}}
$$

9 Where, $\mathrm{VSS}_{\text {out }}$ is the solids leaving the pilot plant and Q is the flow rate, $\mathrm{M}_{\mathrm{t}}$ is the biofilm attached per protected area of carrier media and A is the media protected surface area.

\section{3. Results and discussion}

\subsection{Performance of moving attached growth system during start-up}

The temperature within the cells varied from $18.6 \pm 1.9,19.8 \pm 2.3,20.2 \pm 0.6,17.1 \pm 1.3$ and

$14 \quad 14.6 \pm 1.2^{\circ} \mathrm{C}$ during operation with Media 1, 2, 3, 4 and 5, respectively (Table 2) due to natural annual wastewater temperature fluctuations. Temperature for Media 5 was statistically different from Media 1, 2, 3 and $4(\mathrm{p} \leq 0.05)$. The average total COD influent varied $389 \pm 71$,

$17257 \pm 44,305 \pm 32,236 \pm 15$ and $251 \pm 24 \mathrm{mg} / \mathrm{L}$ for Media 1 to 5 , respectively. Ammonia concentration varied from $35 \pm 5,34 \pm 11,36 \pm 3,38 \pm 6$ and $31 \pm 5 \mathrm{mg} \mathrm{NH}_{4}{ }^{+}-\mathrm{N} / \mathrm{L}$ for Media 1 to

5, respectively. Natural wastewater variability resulted in changes in the COD and ammonia concentrations fed to the pilot plant. The average surface organic loading rate varied between 
$1 \quad 8.7 \pm 1.6,6.8 \pm 1.2,8.3 \pm 0.9,6.8 \pm 0.4$ and $7.0 \pm 0.7 \mathrm{~g}$ total $\mathrm{COD} / \mathrm{m}^{2}$.day for Media $1,2,3,4$ and 5 ,

2 respectively (Table 2 ). Nevertheless, the organic loading rates were statistically similar

3 during the operation with the various media (except for Media 1, which had a different COD

4 loading rate, $\mathrm{p} \leq 0.05$, compared with the other media, but the total $\mathrm{BOD}_{5}$ was statistically

5 similar). Ammonia loadings varied from $0.8 \pm 0.1,0.9 \pm 0.3,1.0 \pm 0.1,1.1 \pm 0.1$ and $0.9 \pm 0.1 \mathrm{~g}$

$6 \mathrm{NH}_{4}{ }^{+}-\mathrm{N} / \mathrm{m}^{2}$.day for Media 1, 2, 3, 4 and 5 respectively. There was no statistical difference

7 between the five media for ammonia loading. The DO was maintained at $4.1 \pm 1.03,4.0 \pm 1.2$,

$8 \quad 3.0 \pm 0.6,5.1 \pm 1.6$ and $3.2 \pm 1.1 \mathrm{mg} \mathrm{O}_{2} / \mathrm{L}$ in Cell 1 and $5.6 \pm 0.5,6.1 \pm 0.9,6.9 \pm 1.2,5.6 \pm 1.1$ and

$9 \quad 6.6 \pm 1.0 \mathrm{mg} \mathrm{O}_{2} / \mathrm{L}$ in Cell 3.

10 The COD removal efficiency and biofilm formation was tracked during the first 60 days

11 of operation. After 6 days of operation the COD removal was high with values of $78,82,78$,

1275 and $79 \%$ with Media 1, 2, 3, 4 and 5, respectively (Fig. 1). The COD removal efficiencies

13 reached stable values of $88 \pm 4 \%$ in Media 1 (after day 18), $81 \pm 4 \%$ in Media 2 (after day 15),

$1485 \pm 3 \%$ in Media 3 (after day 17), 80 $\pm 3 \%$ in Media 4 (after 23 days) and $86 \pm 4 \%$ in Media 5

15 (after 24 days) (Fig. 1a).

16 Throughout the first 10 days of operation, ammonia removal efficiencies were low for all

17 media, with values reaching $24 \pm 7,33 \pm 17,31 \pm 15,24 \pm 11$ and $19 \pm 11 \%$ for Media 1 to 5 ,

18 respectively. Media 1, 2 and 3 (spherical shape) achieved ammonia removal efficiencies of

$1950 \pm 13,64 \pm 13,63 \pm 7 \%$ after 30, 22 and 17 days, respectively. Media 4 and 5 (cylindrical

20 shape) achieved ammonia removal efficiencies of $32 \pm 17 \%$ after 46 days and $34 \pm 5 \%$ after 47

21 days, respectively (Fig. 1b). 
Ammonia removal rates were $0.4 \pm 0.1 \mathrm{~g} \mathrm{NH}_{4}{ }^{+}-\mathrm{N} / \mathrm{m}^{2}$.day (30 days), $0.5 \pm 0.1 \mathrm{~g} \mathrm{NH}_{4}{ }^{+}-$

$2 \mathrm{~N} / \mathrm{m}^{2}$.day (22 days), $0.7 \pm 0.1 \mathrm{~g} \mathrm{NH}_{4}{ }^{+}-\mathrm{N} / \mathrm{m}^{2}$.day (17 days), $0.2 \pm 0.1 \mathrm{~g} \mathrm{NH}_{4}{ }^{+}-\mathrm{N} / \mathrm{m}^{2}$.day (46 days)

3 and $0.3 \pm 0.1 \mathrm{~g} \mathrm{NH}_{4}{ }^{+}-\mathrm{N} / \mathrm{m}^{2}$.day (47 days) for Media 1, 2, 3, 4 and 5, respectively. It is likely

4 that low nitrification was impacted by the concentration of organic matter (BOD) reaching

5 the third cell. Organic loadings were also measured in the different cells during operation.

6 The third cell organic loading rates was $1.4 \pm 0.9,1.6 \pm 0.9,2.1 \pm 1.0,2.8 \pm 0.9$ and $2.9 \pm 0.7 \mathrm{~g}$

$7 \quad \mathrm{BOD}_{5} / \mathrm{m}^{2}$.day when the reactor was operated with Media 1, 2, 3, 4 and 5 respectively. Higher

8 loadings verified in Cell 3 when Media 4 and 5 were used, $2.8 \pm 0.9$ and $2.9 \pm 0.7 \mathrm{~g}$

$9 \mathrm{BOD}_{5} / \mathrm{m}^{2}$.day, respectively. Suggesting that with Media 4 and 5, a lower organic removal

10 occurred in Cell 1 and 2, as the loading rates were kept constant at the influent. The organic

11 loading rate for Cell 3 for Media 4 and 5 were slightly higher than those recommended by

12 Hem et al. (1994) of approximately $<2 \mathrm{~g} \mathrm{BOD}_{5} / \mathrm{m}^{2}$.day. The presence of organics, in the

13 third cell, had promoted growth of heterotrophs and competing nitrifiers slowing down

14 nitrification (Hem et al., 1994). A similar finding was reported by Zhu et al. (2015), which

15 registered only 50\% ammonia removal after 14 days of operation, and the low nitrification

16 was attributed to the high carbon: nitrogen ratio $(\mathrm{C} / \mathrm{N})$. From the data reported in the

17 literature, the range of temperatures measured did not indicate nitrification to be impacted by

18 temperature (temperatures in Cell 3 for Media 4 and $5,17.1 \pm 1.3$ and $14.6 \pm 1.2^{\circ} \mathrm{C}$ respectively)

19 (Salvetti et al., 2006). This is supported by other researchers who have indicated no

20 significant impact on nitrification rate at temperatures of 14,20 and $27^{\circ} \mathrm{C}$ with maximum

21 ammonia removal of 1.69, 1.72 and $1.86 \mathrm{~g} / \mathrm{m}^{2}$.day, respectively (Zhu and Chen, 2002; Daija

22 et al., 2016). 


\section{3.2. Biofilm formation and start-up}

2 In this study, process start-up was defined as the period of time for biofilm formation

3 rates to reach stable values. Bacterial adhesion was observed after the second day of

4 operation, and values of $0.67,0.90,1.21,1.44$ and $1.40 \mathrm{~g} \mathrm{TS} / \mathrm{m}^{2}$ were measured in Media 1,

$52,3,4$ and 5 , respectively (Fig. 2a). This can be defined as the $1^{\text {st }}$ stage of biofilm formation

6 (Zhu et al., 2015).The biofilm continued developing gradually until day 18, 15, 17, 23 and 24

7 for Media 1, 2, 3, 4 and 5, respectively, when the attached biofilm reached stable values

$8\left(8.73,8.66,8.79,8.09\right.$ and $6.38 \mathrm{~g} \mathrm{TS} / \mathrm{m}^{2}$ for Media 1, 2, 3, 4 and 5, respectively) (Fig. 2a).

9 This corresponds to the $2^{\text {nd }}$ and $3^{\text {rd }}$ stages of biofilm growth and accumulation respectively.

10 The biofilm formation rate was calculated based on the slope of the biofilm attachment until

11 it reached stable values (Fig. 2b). The estimated biofilm formation rates during start up were

$120.50,0.52,0.55,0.36$ and $0.27 \mathrm{~g} \mathrm{TS} / \mathrm{m}^{2}$.day for Media $1,2,3,4$ and 5, respectively. The

13 results clearly indicate that the biofilm formation rate was faster on spherical media, with

14 higher voidage and diameter, compared with the cylindrical media, with lower voidage and

15 higher surface area. Di Trapani et al. (2008), stated that one month was required to reach

16 stable conditions, with an attached biofilm of around $11.57 \mathrm{~g} \mathrm{TS} / \mathrm{m}^{2}$ and $15.15 \mathrm{~g} \mathrm{TS} / \mathrm{m}^{2}$ at 35

17 and $65 \%$ filling ratio, respectively using a cylindrical shape carrier media. Falletti et al.

18 (2014) observed a visibly fully grown biofilm after five weeks of operation $\left(39.3 \mathrm{~g} \mathrm{TSS} / \mathrm{m}^{2}\right)$

19 using a cylindrical media. Dong et al. (2015), considered that biofilm was stable and mature

20 in 25 days with a hollow spherical honeycomb and a cylindrical shape carrier media, with

21 attached biofilm of $0.04 \mathrm{~g} / \mathrm{cm}^{3}$. With pre-settled wastewater, Siciliano and De Rosa (2016)

22 observed that heterotrophic biofilm start up required seven days reaching a $3 \mathrm{~g} \mathrm{TS} / \mathrm{m}^{2}$ of 
1 attached biofilm in a cylindrical shape carrier media. Bassin et al. (2016) observed, after 20

2 and 30 days of start-up, a biofilm attached concentration of $13 \mathrm{~g} \mathrm{TS} / \mathrm{m}^{2}$ in a $500 \mathrm{~m}^{2} / \mathrm{m}^{3}$

3 cylindrical shape carrier media and $7 \mathrm{~g} \mathrm{TS} / \mathrm{m}^{2}$ in a $3000 \mathrm{~m}^{2} / \mathrm{m}^{3}$ chip shaped carrier media.

4 For the nitrification process start-up in Cell 3, bacteria attachment was observed on the

5 second day of operation with $0.54,0.31,0.45,0.33,0.48 \mathrm{~g} \mathrm{TS} / \mathrm{m}^{2}$ for Media 1 to 5 ,

6 respectively. The biofilm continued to increase until it attained stabilisation around day 30 ,

$722,17,46$ and 47 for Media 1, 2, 3, 4 and 5, respectively $(6.56,5.48,3.83,9.34,7.57 \mathrm{~g}$

$8 \mathrm{TS} / \mathrm{m}^{2}$, Media 1 to 5, respectively) (Fig. 3a). Others have reported average values of $7 \mathrm{~g}$

$9 \mathrm{TSS} / \mathrm{m}^{2}$ after 1 month on a nitrifying integrated fixed-film activated sludge system (IFAS)

10 start-up using cylindrical shaped carrier media (Regmi et al., 2011). In Bassin et al. (2012)

11 two months were required to start-up a reactor operating under autotrophic conditions using a

12 cylindrical shaped carrier media.

13 The biofilm formation rate was determined based on the slope of the biofilm attached

14 until stable values were reached, from day 0 to day $30,22,17,46$ and 47 . These estimated

15 values were $0.21,0.24,0.22,0.18,0.17 \mathrm{~g} \mathrm{TS} / \mathrm{m}^{2}$.day for Media $1,2,3,4$ and 5 respectively

16 (Fig. 3b). The biofilm formation rate is usually linked with the nitrification rate (Wiesmann,

17 1994). Spherical shape media achieved higher ammonia removal efficiencies (Fig. 3b) and

18 thus a higher biofilm formation rate than cylindrical media.

19 The biofilm thicknesses in Cell 1 were 36, 51, 84, 50 and $82 \mu \mathrm{m}$ on the second day, for

20 Media 1 to 5, respectively (Fig. 4a). The biofilm thickness reached stable values at 225 \pm 52 ,

$21172 \pm 25,195 \pm 35,250 \pm 73$ and $190 \pm 63 \mu \mathrm{m}$ for Media $1,2,3,4$ and 5 at day 18, 15, 17, 23 and

22 24, respectively (Fig. 4a). For the cylindrical media, the biofilm was mainly situated in the 
1 internal fins, in the small ridges of the media and the biofilm thickness attained values

2 between 365-465 $\mu \mathrm{m}$ and 224-361 $\mu \mathrm{m}$ for Media 4 and 5, respectively, by the end of start-up.

3 The biofilm in Media 1, 2 and 3 was spread uniformly. In Cell 3, aimed at ammonia removal,

4 the initial biofilm thickness was $22 \pm 24,31 \pm 30,39 \pm 14,19 \pm 10$ and $28 \pm 11 \mu \mathrm{m}$ for Media 1,2 ,

53,4 and 5 , respectively. The thickness increased to values of $130 \pm 25,71 \pm 22,86 \pm 29,190 \pm 50$

6 and $149 \pm 47 \mu \mathrm{m}$ at day 30,22,17, 46 and 47, respectively (Fig. 4b).

7 Protected surface area of each media was estimated at the macroscopic scale with

8 photography. In Media 1 (large spherical shape), the biofilm was distributed evenly over the

9 media. Approximately $83 \%$ of the carrier media area was covered with biofilm, giving a

10 protected surface area of $112 \mathrm{~m}^{2} / \mathrm{m}^{3}$. For Media 2 and 3 (medium and smaller spherical

11 media) the biofilm was mainly situated in the internal fins, covering 68 and $71 \%$ of the total

12 area (protected surface area of 148 and $220 \mathrm{~m}^{2} / \mathrm{m}^{3}$, respectively). In Media 4 and 5

13 (cylindrical shape) the biofilm was located exclusively on the internal fins. No biofilm

14 attachment was verified on the external surface of Media 4 and 5 . As such 58 and $61 \%$ of

15 Media 4 and 5 were covered with biofilm, yielding a protected surface area of 348 and 610

$16 \mathrm{~m}^{2} / \mathrm{m}^{3}$, respectively.

17 During the first days of operation, a similar EPS profile was observed for all the media in

18 Cell 1 (organic removal). The EPS concentration increased, reaching values of $20.6 \pm 0.4$,

$1921.3 \pm 0.3,28.3 \pm 0.1,28.2 \pm 0.75$ and $27.4 \pm 0.81 \mathrm{mg}$ tEPS /g VSS for Media 1, 2, 3, 4 and 5,

20 respectively (Fig. 5a). As expected, the EPS production was higher throughout the first days

21 of operation due to the adhesion phenomena and interaction between the heterotrophic

22 bacteria and the carrier surface (Badireddy et al., 2010). A gradual increase in total EPS was 
1 also observed in Tang et al. (2017) with values of 15, 22, 32.5 and $38 \mathrm{mg}$ tEPS /g VSS

2 measured at the initial stage of biofilm formation (0, 3, 11, 18 and day 25 days). Similar

3 observations, also identified by Tang et al. (2015) demonstrated an increase from $30 \mathrm{mg}$ EPS

4 /g VSS on day 5 up to $250 \mathrm{mg}$ EPS/g VSS on day 27. In Oberoi and Philip (2017) the

5 concentration of EPS increased from 36.8 to $72.2 \mathrm{mg}$ EPS/g VSS at the end of start-up. Total

6 EPS content in an IFAS varied from 44 to $71 \mathrm{mg}$ tEPS/g VSS using different media

7 (Mahendran et al., 2012).

A gradual decrease in EPS concentration was observed after the first week and values

9 stabilised at $16.0 \pm 0.4,18.2 \pm 0.9,9.18 \pm 0.1,11.83 \pm 0.9$ and $12.83 \pm 0.2 \mathrm{mg}$ tEPS/g VSS on day

$1016,15,19,17$ and 16 for Media 1, 2, 3, 4 and 5, respectively. As predicted the values of EPS

11 decreased after bacteria adhesion and growth. As the biofilm grows in thickness, diffusion

12 becomes critical, and cells start to grow slower reducing EPS production and biofilm

13 cohesion resulting in biofilm detachment (Ahimou et al., 2007). After day 25 a gradual

14 decrease in EPS production was also observed in Tang et al. (2017) during the maturity and

15 detachment phases.

16 The total EPS associated with the biofilm in Cell 3 of the pilot plant during the first days

17 of operation were $22.1 \pm 0.5,22.5 \pm 0.4,20.1 \pm 0.3,27.3 \pm 0.6$ and $34.8 \pm 1.9 \mathrm{mg}$ tEPS/g VSS for

18 Media 1, 2, 3, 4 and 5, respectively (Fig. 5b). Similarly, the EPS decreased as operation

19 progressed. After days 30, 22, 17, 46 and 47 days of operation, the EPS were 17.2 \pm 0.3 ,

$205.7 \pm 0.3,6.6 \pm 0.1,10.6 \pm 0.1$ and $9.7 \pm 0.3 \mathrm{mg}$ tEPS/g VSS for Media 1, 2, 3, 4 and 5,

21 respectively. Values of EPS were very similar between the first cell and third cell.

22 Nonetheless, nitrifiers are slow growing bacteria with low EPS production compared to 
1 heterotrophic bacteria. The high EPS formation in Cell 3, might have been produced by

2 heterotrophic bacteria due to the high COD reaching the third cell during start-up. Bassin et

3 al. (2012) stated that EPS produced by heterotrophic bacteria were utilised by nitrifiers for

4 biofilm formation during start-up.

5 During start up the biofilm attached on carrier per amount of COD converted was

6 compared between media. Values of $0.26,0.27,0.28,0.65$ and $0.41 \mathrm{~g}$ VSS/g COD were

7 calculated in Media 1, 2, 3, 4 and 5, respectively (Fig. 6a). The higher biomass yield achieved

8 in media 4 and 5 correlated well with the lower biofilm formation rate estimated during the

9 start-up period. Values of $0.5 \mathrm{~g} \mathrm{SS} / \mathrm{g}$ filtered COD are reported on the literature (Ødegaard,

10 2006). An initial detachment rate coefficient was calculated based on a mass balance between

11 the solids leaving the reactor and the biofilm attached per area of carrier media (Eldyasti et

12 al., 2012). The normalised average detachment rate (1/d) was compared between media, and

13 the attached biofilm considered for COD removal was from Cell 1 of the reactor. Due to the

14 dynamic of biofilm accumulation in moving attached growth systems, detachment rates

15 displayed significant variations during the start-up for all the five media studied. Values of

$160.24 \pm 0.10,0.29 \pm 0.14,0.37 \pm 0.18,0.80 \pm 0.25$ and $0.66 \pm 0.251 / \mathrm{d}$ were measured in Cell 1 for

17 Media 1 to 5, respectively (Fig. 6b). Media 4 and 5 (cylindrical shape) promoted higher

18 detachment due to interaction with aeration during initial biofilm formation, while the open

19 spherical structure of Media 1,2 and 3 enhanced initial biofilm formation, protecting the

20 biofilm from shear. Values of $0.12 \mathrm{~g} \mathrm{VSS} / \mathrm{g}$ COD and detachment rates of $0.05 \mathrm{1} / \mathrm{d}$ were

21 reported in Eldyasti et al. (2012) for a high spherical media compared with $0.19 \mathrm{~g} \mathrm{VSS} / \mathrm{g}$

22 COD and detachment rates of $0.171 / \mathrm{d}$ for a low sphericity media. 


\section{4. Influence of the media physical properties on start-up duration}

2 In moving attached growth systems, the main factor assuring a fast start-up is the biofilm

3 development. In this study start-up duration was assessed based on the attached biofilm ( $\mathrm{g}$

$4 \mathrm{TS} / \mathrm{m}^{2}$ ). In order to study the influence of media physical properties on the pilot plant start-

5 up, the biofilm formation rate was correlated with media physical properties. The media

6 physical properties were previously identified in Dias et al. (2018), to correlate with process

7 hydrodynamics and oxygen mass transfer. More specifically, media dimensionality (Di) and

8 voidage (Voi) were found to strongly correlate with oxygen mass transfer $\left(\mathrm{R}^{2}=0.89\right)$ and

9 pilot plant hydraulic efficiency $(\mathrm{HE})\left(\mathrm{R}^{2}=0.92\right)$ both in clean media and with biofilm

10 attached to the media (Dias et al., 2018). Hydraulic efficiency (HE) was determined through

11 tracer studies using Rhodamine and calculated based on the ratio between mean residence

12 time and hydraulic retention time (tm/HRT).

13 When the rate of biofilm formation in Cell 1 (COD removal) and Cell 3 (ammonia removal)

14 was compared with the media protected surface area, good correlations were achieved $\left(\mathrm{R}^{2}\right.$ of

150.83 and $\mathrm{R}^{2}$ of 0.76 , respectively) (Fig. 7a). A stronger correlation was identified between the

16 combination of parameters (Di x Voi)/HE, and the rate of biofilm formation during COD

17 removal start up $\left(\mathrm{R}^{2}=0.95\right)$ and an $\mathrm{R}^{2}$ of 0.92 during ammonia removal start-up (Fig. $\left.7 \mathrm{~b}\right)$.

18 The physical media properties and hydraulic efficiency clearly demonstrate the

19 importance of media shape and size on biofilm attachment and start-up. Biofilm formation

20 rates were $30 \pm 1 \%$ higher in the spherical media during organic removal start-up and $20 \pm 3 \%$

21 higher during ammonia removal start-up, when compared with cylindrical media. The high

22 voidage (95, 92 and 90\%) and open structure of spherical media (Media 1, 2 and 3) was 
1 associated with higher hydraulic efficiencies $(89 \pm 2,93 \pm 5$ and $100 \%)$ as outlined in Dias et al.

2 (2018). This led to increased oxygen mass transfer offering better conditions for biofilm to

3 attach, leading to a faster start-up. In turn this provided, improved mass transfer at the

4 bulk/biofilm interface increasing biofilm activity and treatment performance (Tang et al.,

5 2017). The reduction on hydraulic efficiencies and media voidage, obtained with cylindrical

6 media (Media 4: HE 74 $\pm 1 \%$ and Voi reduction of 6\%; Media 5: HE $63 \pm 2 \%$ and Voi

7 reduction of 14\%) (Dias et al., 2018), explained the longer start-up (46 and 47 days).

The diffusion of oxygen is usually limited after a critical biofilm thickness of 50-150

$9 \mu \mathrm{m}$ (Syron and Casey, 2008). Values of biofilm thickness of $190 \pm 50$ and $149 \pm 47 \mu \mathrm{m}$ were

10 measured in Media 4 and 5 during start-up. Despite the higher protected surface area of

11 Media 4 and 5 the start-up duration and biofilm formation rate were slower compared with

12 the lower protected surface area (Media 1, 2 and 3). This confirms the contribution and the

13 important roles played by other properties in the media. Similar observations were stated in

14 Bassin et al. (2016) where higher attached biofilm concentrations were reached in a smaller

15 protected surface area media compared with higher protected surface area media. In Eldyasti

16 et al. (2012) work, surface shape (sphericity), played an important role on biofilm structure

17 with $70 \%$ lower biofilm yield and detachments rate observed on high sphericity media (0.9)

18 compared to low sphericity media (0.5).

19 The open spherical structure of Media 1, 2 and 3 notwithstanding the lower protected

20 surface area, favoured wastewater circulation and oxygen distribution within all areas of the

21 media. Therefore, this study highlights the importance of media physical properties on

22 biofilm growth and retention and their impact on the start-up duration on moving attached 
1 growth systems. The knowledge gained through this study will challenge current literature

2 knowledge and commercial strategies that appointed the protected surface area as the key

3 factor for the design and operation of moving attached growth system (Ødegaard et al.,

4 2000). Findings highlighted the importance of voidage on biofilm growth and maintenance

5 and thus on treatment performance during start-up.

6 Hence, considering the importance of start-up to achieve stable operational

7 performance at low commission periods, the economic competitiveness of the moving

8 attached growth system technology can be improved through additional focus on carrier

9 media properties (voidage and shape).

10 5. Conclusions

11 In this study, the influence of carrier media physical properties on the start-up duration of a

12 moving attached growth system was investigated. Start-up was monitored using the biofilm

13 formation rate. Faster biofilm formation rates were obtained for COD removal and ammonia

14 removal when spherical media was used. Stronger correlations were observed between the

15 biofilm formation rates and the combination of physical factors and hydraulic efficiency (Di

$16 \mathrm{x}$ Voi)/HE for COD and ammonia removal rates. This study highlighted that the conventional

17 way to design moving attached growth systems should not be exclusively according to its

18 protected surface area and future moving attached growth system design and evaluation

19 should focus equally on carrier media physical properties.

\section{Acknowledgements}

22 The authors acknowledge the financial support from Warden Biomedia and Cranfield 23 University. 


\section{Appendix A. Supplementary data}

2 Supplementary data associated with this article can be found

3

4

5

6

7

\section{References}

Ahimou, F., Semmens, M.J., Haugstad, G., Novak, P.J., 2007. Effect of protein, polysaccharide, and oxygen concentration profiles on biofilm cohesiveness. Appl. Environ. Microbiol. 73, 2905-2910.

APHA, 2005. Standard Methods for the Examination of Water and Wastewater, 21st ed. American Public Health Association, Washington, D.C.

Badireddy, A.R., Chellam, S., Gassman, P.L., Engelhard, M.H., Lea, A.S., Rosso, K.M., 2010. Role of extracellular polymeric substances in bioflocculation of activated sludge microorganisms under glucose-controlled conditions. Water Res. 44, 4505-4516.

Barwal, A., Chaudhary, R., 2016. Feasibility study for the treatment of municipal wastewater by using a hybrid bio-solar process. J. Environ. Manage. 177, 271-277.

Bassin, J.P., Dias, I.N., Cao, S.M.S., Senra, E., Laranjeira, Y., Dezotti, M., 2016. Effect of increasing organic loading rates on the performance of moving-bed biofilm reactors filled with different support media: Assessing the activity of suspended and attached biomass fractions. Process Saf. Environ. Prot. 100, 131-141.

Bassin, J.P., Kleerebezem, R., Rosado, A.S., Van Loosdrecht, M.C.M., Dezotti, M., 2012. Effect of different operational conditions on biofilm development, nitrification, and nitrifying microbial population in moving-bed biofilm reactors. Environ. Sci. Technol. $46,1546-1555$.

Daija, L.; Selberg A., Rikmann E., Zekker I., Tenno T., Tenno T., 2016. The influence of lower temperature, influent fluctuations and long retention time on the performance of an upflow mode laboratory-scale septic tank. Desal and Water Treatme. 57,1-9. 
2 Deng, L., Guo, W., Ngo, H.H., Zhang, X., Wang, X.C., Zhang, Q., Chen, R., 2016. New functional biocarriers for enhancing the performance of a hybrid moving bed biofilm reactor-membrane bioreactor system. Bioresour. Technol. 208, 87-93.

Dias, J., Stephenson, T., Bellingham, M., Hassan, J., Barrett, M., Soares, A., 2018. Impact of carrier media on oxygen transfer and wastewater hydrodynamics on a moving attached growth system. Chem. Eng. J. Submitted.

Di Trapani, D., Mannina, G., Torregrossa, M., Viviani, G., 2008. Hybrid moving bed biofilm reactors: A pilot plant experiment. Water Sci. Technol. 57, 1539-1545.

Dong, Y., Fan, S.-Q., Shen, Y., Yang, J.-X., Yan, P., Chen, Y.-P., Li, J., Guo, J.-S., Duan, X.M., Fang, F., Liu, S.-Y., 2015. A Novel Bio-carrier fabricated using 3D printing technique for wastewater treatment. Sci. Rep. 5, 1-10.

Dubois, M., Gilles, K.A., Hamilton, J.K., Rebers, P.A., Smith, F., 1956. Colorimetric method for determination of sugars and related substances. Anal Chem 28, 350-356.

Eldyasti, A., Nakhla, G., Zhu, J., 2012. Influence of particles properties on biofilm structure and energy consumption in denitrifying fluidized bed bioreactors (DFBBRs). Bioresour. Technol. 126, 162-171.

Falletti, L., Conte, L., Maestri, A., 2014. Upgrading of a wastewater treatment plant with a hybrid moving bed biofilm reactor (MBBR). AIMS Environ. Sci. 1, 45-52.

Goel, R., Kaldate, A., Murthy, S., Schraa, O., Stinson, B., 2011. Examining the phenomenon of self regulation of biofilm density under dynamic conditions using a biofilm model, in: WEFTEC 2011. Water Environment Federation, Los Angeles, pp. 5160-5177.

Habouzit, F., Hamelin, J., Santa-Catalina, G., Steyer, J.P., Bernet, N., 2014. Biofilm development during the start-up period of anaerobic biofilm reactors: The biofilm Archaea community is highly dependent on the support material. Microb. Biotechnol. 7, $257-264$. 
1 Hem, L.J., Rusten, B., Odegaard, H., 1994. Nitrification in a moving bed biofilm reactor. Water Res. 28, 1425-1433.

3 Holloway, T.G., Soares, A., 2018. Influence of internal fluid velocities and media fill ratio on submerged aerated filter hydrodynamics and process performance for municipal wastewater treatment. Process Saf. Environ. Prot. 114, 179-191.

Lackner, S., Holmberg, M., Terada, A., Kingshott, P., Smets, B.F., 2009. Enhancing the formation and shear resistance of nitrifying biofilms on membranes by surface modification. Water Res. 43, 3469-3478.

Le-Clech, P., Chen, V., Fane, T.A.G., 2006. Fouling in membrane bioreactors used in wastewater treatment. J. Memb. Sci. 284, 17-53.

Leyva-Díaz, J.C., Calderón, K., Rodríguez, F.A., González-López, J., Hontoria, E., Poyatos, J.M., 2013. Comparative kinetic study between moving bed biofilm reactor-membrane bioreactor and membrane bioreactor systems and their influence on organic matter and nutrients removal. Biochem. Eng. J. 77, 28-40.

Liu, Y., Tay, J.H., 2002. The essential role of hydrodynamic shear force in the formation of biofilm and granular sludge. Water Res. 36, 1653-1665.

Lowery, O.H., Rosebrough, N.J., Farr, A.L., Randall, R.J., 1951. Protein measurement with the folin phenol reagent. J. Biol. Chem. 193, 265-275.

Mahendran, B., Lishman, L., Liss, S.N., 2012. Structural, physicochemical and microbial properties of flocs and biofilms in integrated fixed-film activated sludge (IFFAS) systems. Water Res. 46, 5085-5101.

Mao, Y., Quan, X., Zhao, H., Zhang, Y., Chen, S., Liu, T., Quan, W., 2017. Accelerated startup of moving bed biofilm process with novel electrophilic suspended biofilm carriers. Chem. Eng. J. 315, 364-372.

Oberoi, A.S., Philip, L., 2017. Performance evaluation of attached biofilm reactors for the treatment of wastewater contaminated with aromatic hydrocarbons and phenolic 
2 Ødegaard, H., 2016. A road-map for energy-neutral wastewater treatment plants of the future based on compact technologies (including MBBR). Front. Environ. Sci. Eng. 10, 1-17.

4

Ødegaard, H., 2006. Innovations in wastewater treatment: The moving bed biofilm process. Water Sci. Technol. 53, 17-33.

Ødegaard, H., Gisvold, B., Strickland, J., 2000. The influence of carrier size and shape in the moving bed biofilm process. Water Sci. Technol. 41, 383-391.

Patel, A., Nakhla, G., Zhu, J., 2005. Detachment of multi species biofilm in circulating fluidized bed bioreactor. Biotechnol. Bioeng. 92, 427-437.

Pellicer-Nàcher, C., Smets, B.F., 2014. Structure, composition, and strength of nitrifying membrane-aerated biofilms. Water Res. 57, 151-161.

Regmi, P., Thomas, W., Schafran, G., Bott, C., Rutherford, B., Waltrip, D., 2011. Nitrogen removal assessment through nitrification rates and media biofilm accumulation in an IFAS process demonstration study. Water Res. 45, 6699-6708.

Rikmann, E., Zekker, I., Tenno, T., Saluste, A., Tenno, T., 2018. Inoculum-free start-up of biofilm- and sludge-based deammonification systems in pilot scale. Int. J. Environ. Sci. Technol. 15, 133-148.

Rikmann, E., Zekker, I., Tomingas, M., Tenno, T., Loorits, L., Vabamäe, P., Mandel, A., Raudkivi, M., Daija, L., Kroon, K., Tenno, T., 2014. Sulfate-reducing anammox for sulfate and nitrogen containing wastewaters. Desalin. Water Treat. 57, 3132-3141.

Rikmann, E., Zekker, I., Tomingas, M., Vabamäe, P., Kroon, K., Saluste, A., Tenno, T., Menert, A., Loorits, L., Rubin, S.S., Tenno, T., 2015. Comparison of sulfate-reducing and conventional Anammox upflow anaerobic sludge blanket reactors. J Biosci and Bioeng 118 (4), 426-433.

Salvetti, R., Azzellino, A., Canziani, R., Bonomo, L., 2006. Effects of temperature on tertiary 
nitrification in moving-bed biofilm reactors. Water Res. 40, 2981-2993.

2 Siciliano, A., De Rosa, S., 2016. An experimental model of COD abatement in MBBR based on biofilm growth dynamic and on substrates' removal kinetics. Environ. Technol. (United Kingdom) 37, 2058-2071.

5

6

7

8

Syron, E., Casey, E., 2008. Membrane-aerated biofilms for high rate biotreatment: Performance appraisal, engineering principles, scale-up, and development requirements. Environ. Sci. Technol. 42, 1833-1844.

Szilágyi, N., Kovács, R., Kenyeres, I., Csikor, Z., 2013. Biofilm development in fixed bed biofilm reactors: experiments and simple models for engineering design purposes. Water Sci. Technol. 68, 1391-1399.

Tang, B., Yu, C., Bin, L., Zhao, Y., Feng, X., Huang, S., Fu, F., Ding, J., Chen, C., Li, P., Chen, Q., 2016. Essential factors of an integrated moving bed biofilm reactor-membrane bioreactor: Adhesion characteristics and microbial community of the biofilm. Bioresour. Technol. 211, 574-583.

Tang, B., Zhao, Y., Bin, L., Huang, S., Fu, F., 2017. Variation of the characteristics of biofilm on the semi-suspended bio-carrier produced by a $3 \mathrm{D}$ printing technique: Investigation of a whole growing cycle. Bioresour. Technol. 244, 40-47.

Tenno, T., Rikmann, E., Zekker, I., Tenno, T., L., Mashirin, A., 2016. Modelling equilibrium distribution of carbonaceous ions and molecules in a heterogeneous system of $\mathrm{CaCO} 3-$ water-gas., in: Proceedings of the Estonian Academy of Sciences. p. 68.

Wiesmann, U., 1994. Biological nitrogen removal from wastewater. Adv. Biochem. Eng. Biotechnol. 51, 114-153.

Zekker, I., Rikmann, E., Kroon, K., Mandel, A., Mihkelson, J., Tenno, T., Tenno, T., 2017. Ameliorating nitrite inhibition in a low-temperature nitritation-anammox MBBR using bacterial intermediate nitric oxide. Int. J. Environ. Sci. Technol. 14, 2343-2356.

Zekker, I., Rikmann, E., Mandel, A., Kroon, K., Seiman, A., Mihkelson, J., Tenno, T., 
1 Toomas, T., 2016. Step-wise temperature decreasing cultivates a biofilm with high 2 nitrogen removal rates at $9^{\circ} \mathrm{C}$ in short-term anammox biofilm tests. Environ. Technol. $3 \quad 37,1933-1946$.

4 Zekker, I., Rikmann, E., Tenno, T., Vabamäe, P., Tomingas, M., Menert, A., Loorits, L., 5 Tenno, T., 2012. Anammox Bacteria Enrichment and Phylogenic Analysis in Moving $6 \quad$ Bed Biofilm Reactors. Environ. Eng. Sci. 29, 946-950.

7 Zhu, S., Chen, S., 2002. The impact of temperature on nitrification rate in fixed biofilters. 8 Aquac. Eng. 26, 221-237.

9 Zhu, Y., Zhang, Y., Ren, H. qiang, Geng, J. ju, Xu, K., Huang, H., Ding, L. li, 2015. 10 Physicochemical characteristics and microbial community evolution of biofilms during the start-up period in a moving bed biofilm reactor. Bioresour. Technol. 180, 345-351. 

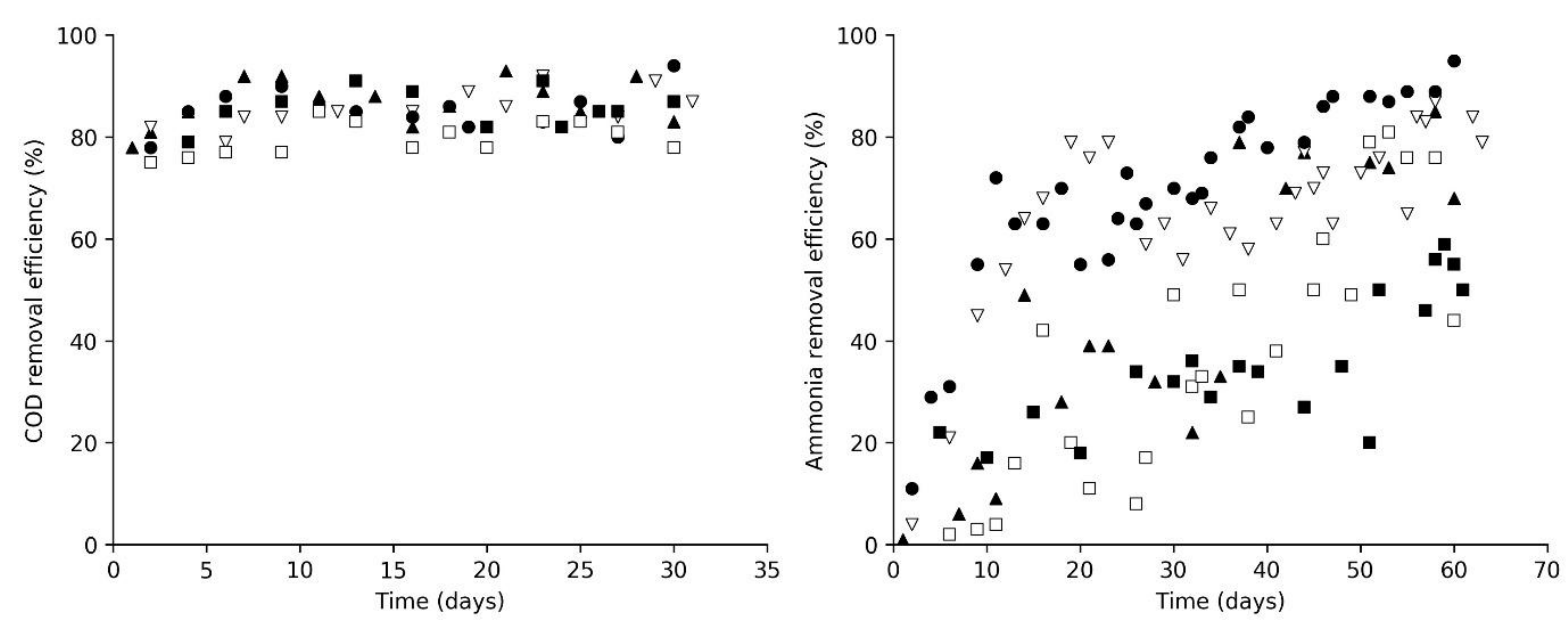

Figure 1 Removal efficiencies for obtainable COD (a) and ammonia (b) during start-up during operation with Media 1, 2, 3, 4 and 5, respectively. 
(a)

(b)
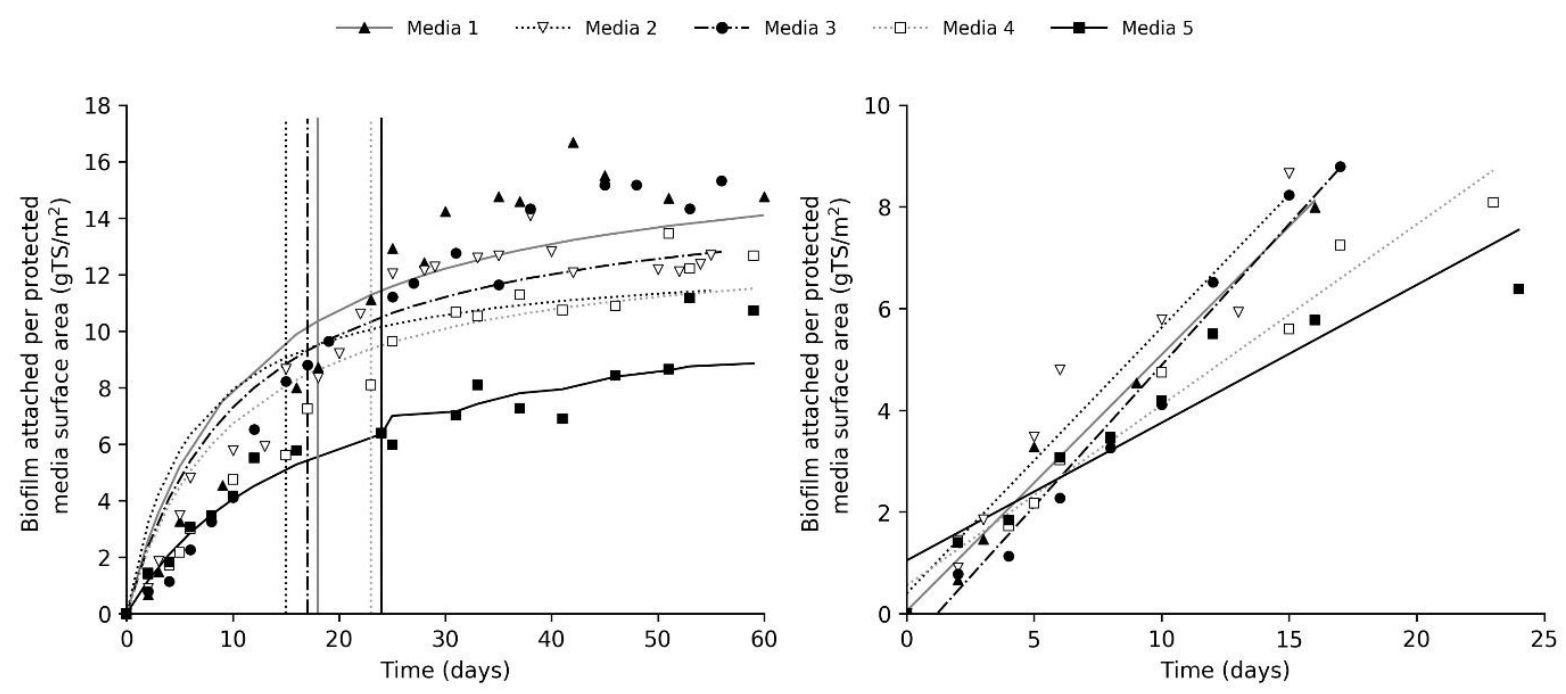

Figure 2 Biofilm attachment during 60 days of operation in cell 1 (COD removal) (a) and fitting of trend-line to calculate slope corresponding biofilm formation rate (b) during startup. 
(a)

(b)
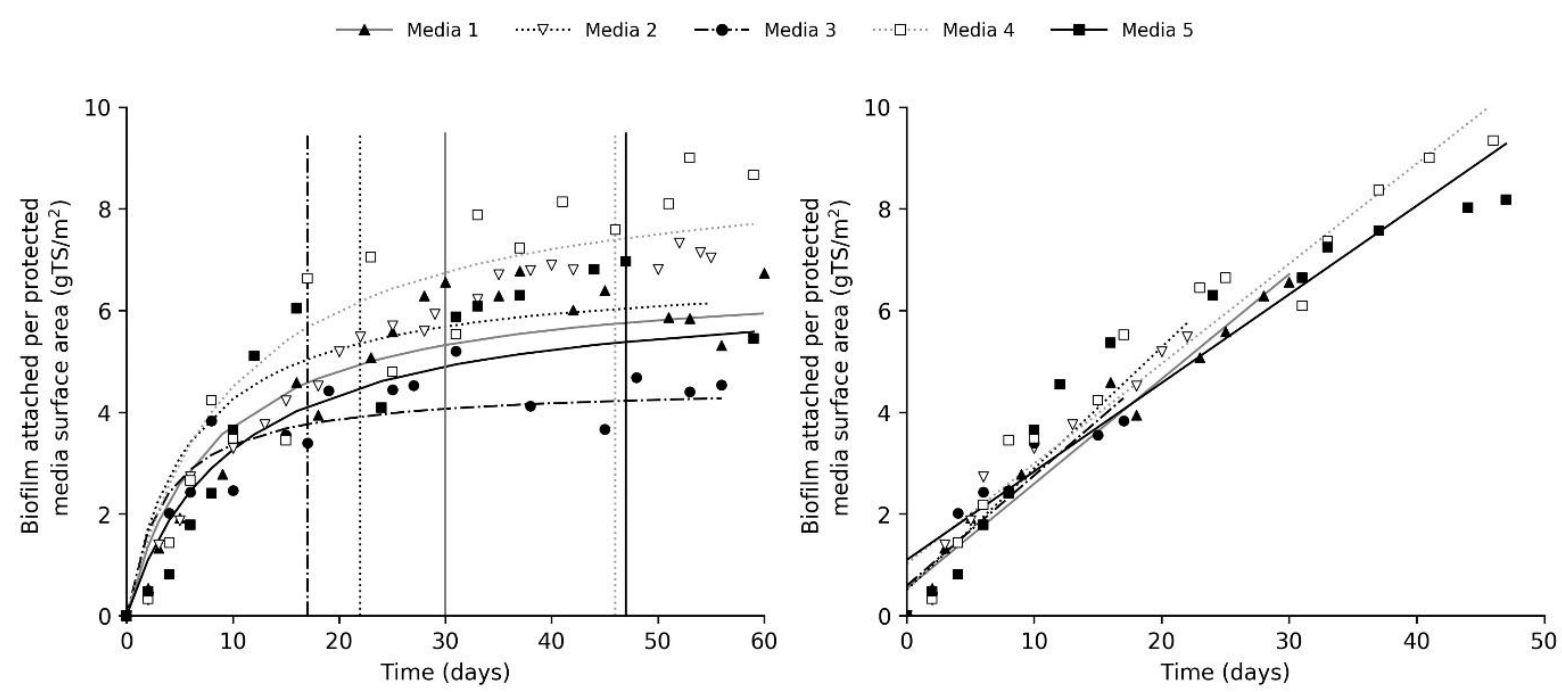

Figure 3 Biofilm attached during the 60 days of operation in Cell 3 (ammonia removal) (a) and fitting of trendline to calculate slope corresponding biofilm formation rate (b) during start-up. 
(a)

(b)

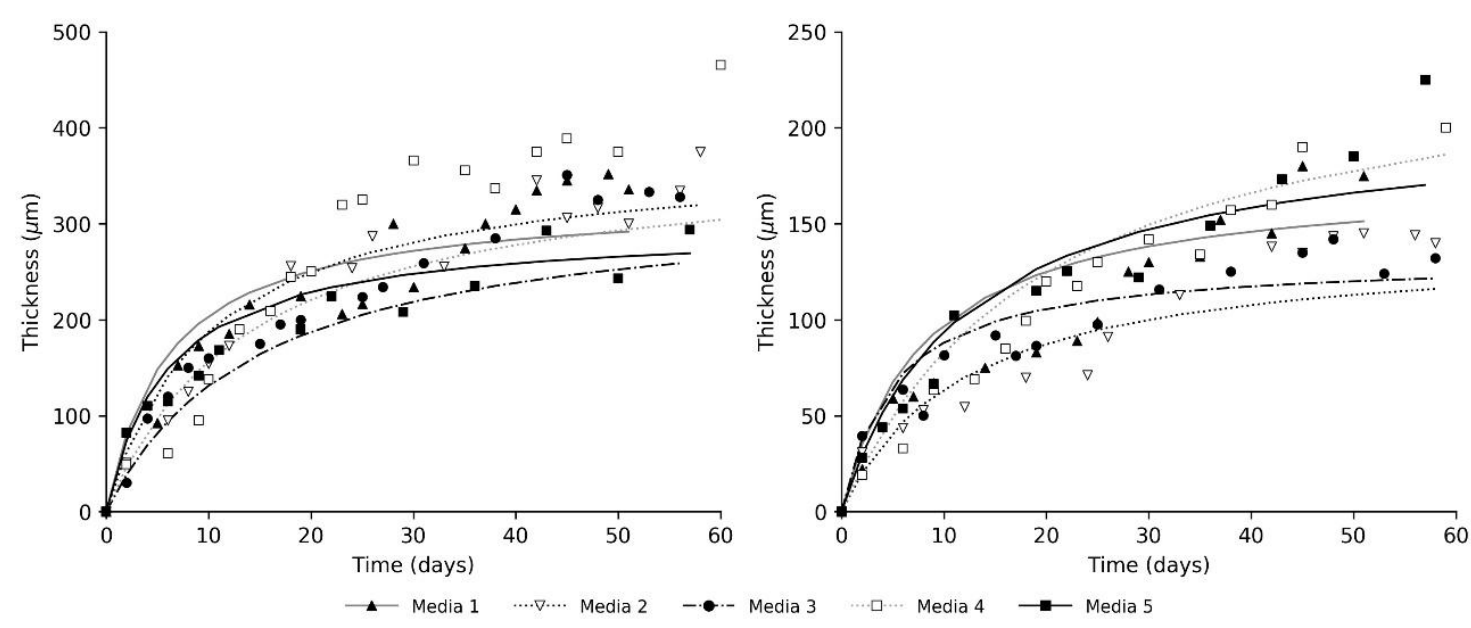

Figure 4 Biofilm thickness during 60 days of operation Cell 1(a) and Cell 3 (b). 
(a)

(b)
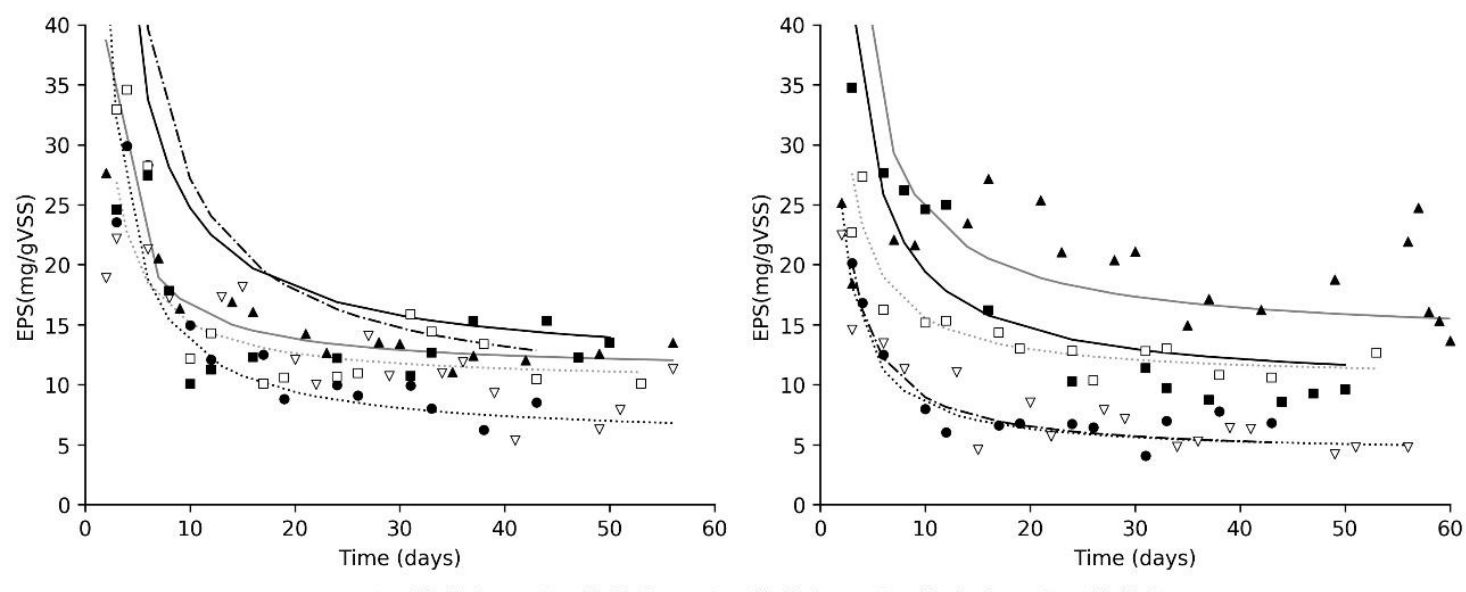

Figure 5 Total EPS values registered in Cell 1 (a) and Cell 3 (b) during 60 days of operation. 
(a)

(b)
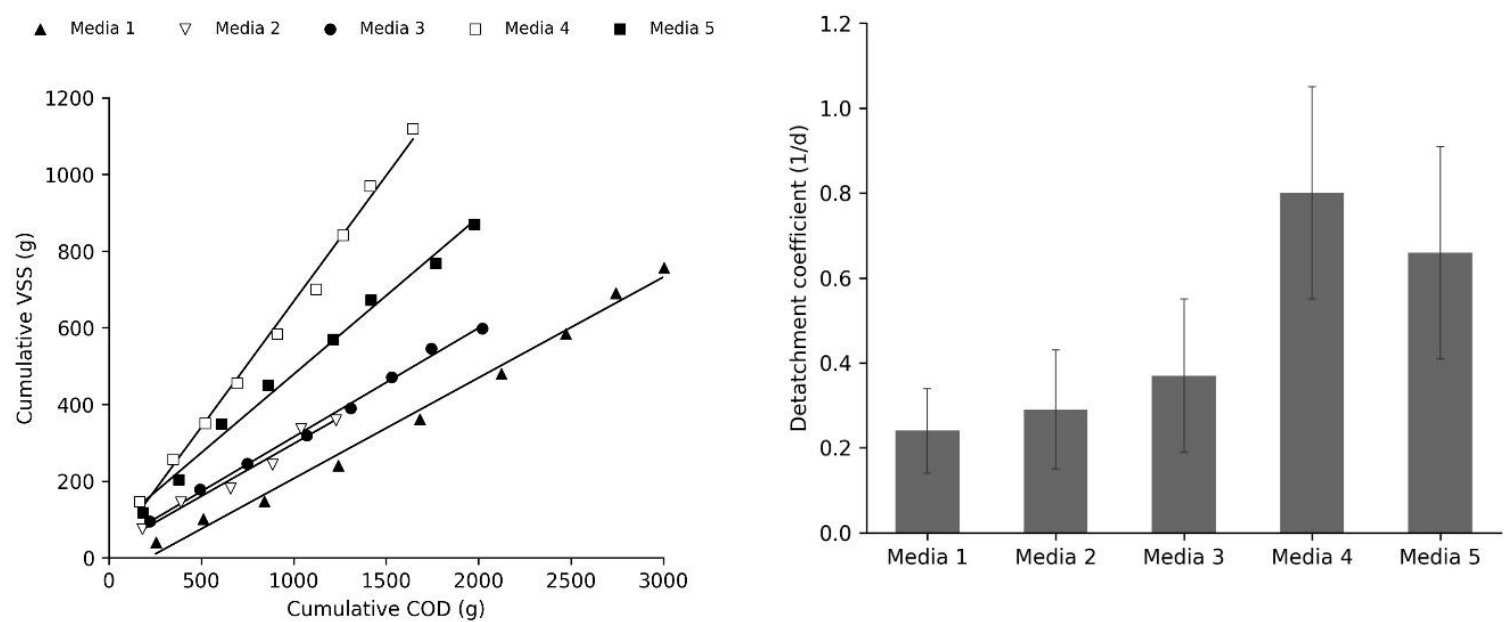

Figure 6 Biofilm yield (a) and biofilm detachment rate (b) calculated for the five media during COD start-up. 
(a)

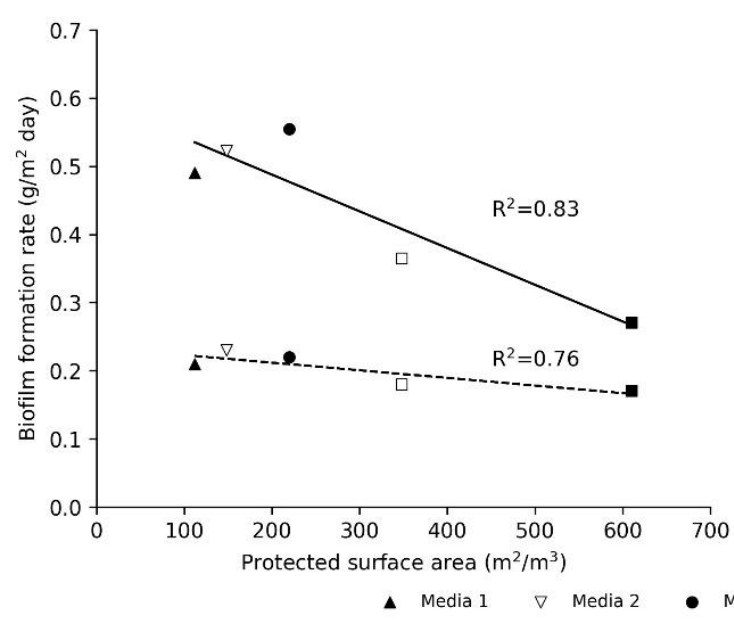

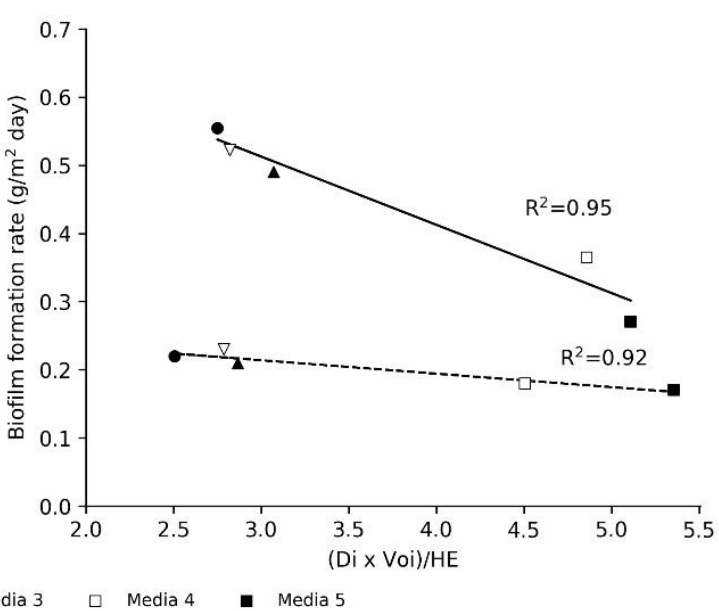

(b)

Figure 7 Correlation between biofilm formation rate and protected surface area (a) and combination of parameters (Di x Voi)/HE (b) during COD (-) and ammonia removal start-up $(--)$. 


\section{Table 1}

Media characteristics used in this study. Media 1 (Biofil), Media 2 (Bioball), Media 3 (Biomarble), Media 4 (Biopipe) and Media 5 (Biotube). Media was supplied by Warden Biomedia (http://www.wardenbiomedia.com).

\begin{tabular}{|c|c|c|c|c|c|c|c|c|}
\hline \multirow[b]{2}{*}{ Media } & \multirow{2}{*}{$\begin{array}{c}\text { Total } \\
\text { surface } \\
\left(\mathbf{m}^{2} / \mathbf{m}^{3}\right)\end{array}$} & \multirow{2}{*}{$\begin{array}{c}\text { Protected } \\
\text { surface } \\
\text { area } \\
\left(\mathrm{m}^{2} / \mathrm{m}^{3}\right)\end{array}$} & \multirow[t]{2}{*}{ Shape } & \multicolumn{2}{|c|}{ Dimensions } & \multirow{2}{*}{$\begin{array}{c}\text { Voidage } \\
(\%)\end{array}$} & \multirow[t]{2}{*}{ Material } & \multirow{2}{*}{$\begin{array}{r}\text { Density } \\
\left(\mathrm{g} / \mathrm{cm}^{3}\right)\end{array}$} \\
\hline & & & & $\begin{array}{l}\text { Length } \\
\text { (mm) }\end{array}$ & $\begin{array}{l}\text { Diameter } \\
\text { (mm) }\end{array}$ & & & \\
\hline 1 & 135 & 112 & Spherical & 65 & 95 & 95 & & \\
\hline 2 & 220 & 148 & Spherical & 53 & 65 & 92 & & \\
\hline 3 & 310 & 220 & Spherical & 36 & 46 & 90 & Recycled & 0.97 \\
\hline 4 & 600 & 348 & Cylindrical & 13 & 21.5 & 82.5 & (PP) & \\
\hline 5 & 1000 & 610 & Cylindrical & 8 & 12 & 80 & & \\
\hline
\end{tabular}


Table 2

Characterisation of the wastewater fed to the pilot plant operated with different media during start up.

\begin{tabular}{|c|c|c|c|c|c|c|}
\hline Parameter & Unit & Media 1 & Media 2 & Media 3 & Media 4 & Media 5 \\
\hline Temperature & ${ }^{\circ} \mathrm{C}$ & $15.1 \pm 2.2$ & $19.2 \pm 2.2$ & $20.9 \pm 1.7^{*}$ & $13.8 \pm 2.3^{*}$ & $13.1 \pm 1.8$ \\
\hline $\mathbf{p H}$ & & $7.6 \pm 0.1$ & $8.0 \pm 0.2$ & $7.7 \pm 0.2$ & $7.7 \pm 0.3$ & $8.1 \pm 0.2$ \\
\hline Total COD (tCOD) & $\mathrm{mg} / \mathrm{L}$ & $389 \pm 71$ & $257 \pm 44$ & $305 \pm 32$ & $236 \pm 15$ & $251 \pm 24$ \\
\hline $\begin{array}{l}\text { Particulate COD } \\
\text { (pCOD) }\end{array}$ & $\mathrm{mg} / \mathrm{L}$ & $317 \pm 77$ & $189 \pm 41$ & $234 \pm 30$ & $147 \pm 20$ & $187 \pm 25$ \\
\hline Soluble COD (sCOD) & $\mathrm{mg} / \mathrm{L}$ & $72 \pm 7$ & $68 \pm 12$ & $71 \pm 5$ & $89 \pm 11$ & $63 \pm 8$ \\
\hline $\mathrm{BOD}_{5}$ & $\mathrm{mg} / \mathrm{L}$ & $143 \pm 47$ & $81 \pm 28$ & $125 \pm 27$ & $158 \pm 39$ & $148 \pm 38$ \\
\hline Soluble $\mathrm{BOD}_{5}\left(\mathrm{sBOD}_{5}\right)$ & $\mathrm{mg} / \mathrm{L}$ & $11 \pm 6$ & $18 \pm 2$ & $22 \pm 4$ & $37 \pm 8$ & $32 \pm 9$ \\
\hline TSS & $\mathrm{mg} / \mathrm{L}$ & $225 \pm 54$ & $154 \pm 88$ & $205 \pm 45$ & $162 \pm 33$ & $202 \pm 78$ \\
\hline $\operatorname{Ammonia}\left(\mathrm{NH}_{4}{ }^{+}-\mathrm{N}\right)$ & $\mathrm{mg} / \mathrm{L}$ & $35 \pm 5$ & $34 \pm 11$ & $36 \pm 3$ & $38 \pm 6$ & $31 \pm 5$ \\
\hline
\end{tabular}

